\title{
IKAP.P
}

JKAP (Jurnal Kebijakan dan Administrasi Publik)

Vol.20 (2), November 2016, 9-23

ISSN 0852-9213 (Print), ISSN 2477-4693 (Online)

Available Online at https://journal.ugm.ac.id/jkap

\section{Getting Out of the Trap of War on Drugs}

\author{
Erwinton Simatupang \\ Departemen Pembangunan Sosial dan Kesejahteraan \\ Fakultas Ilmu Sosial dan Ilmu Politik, Universitas Gadjah Mada \\ erwinton.simatupang@gmail.com
}

\begin{abstract}
The aim of this paper is to reveal several factors why war on drugs is still adopted by The Indonesian government and to offer an alternative approach as a problem solver. Therefore, the paper utilizes a literature review by collecting data from books, journals, news articles, and research reports. The results indicate that some factors consist of: (a) The New Order as previous generation failed to notice the dangers of drugs; (b) Since the New Order, the government is not committed to reveal the involvement of political actors in the drug problem; (c), SBY did not show a firm attitude to the drug problem; (d), Jokowi is the product of the previous generation, the New Order, who may believe that drug issues can be solved by legal approach; (e) Political affiliation between Jokowi and Megawati at PDI-P; (f) The war on drugs is a populist policy and can not be separated from political interests. As a result, war on drugs in Indonesia is war on young generation because the greatest victim of the policy is the lives of the young generation. To get out of this trap, the government should prevent individuals and groups from social exclusion because social dimensions frequently precede the drug issues and become a stumbling block for those who are addicted to get out of the drug problem.
\end{abstract}

Keywords: drugs, social exclusion, war on drugs 


\section{INTRODUCTION}

Since elected as a president, Joko Widodo continuously campaigns war on drugs. Admittedly, according to the National Narcotics Agency (BNN) data, the number of drug abusers has gone up, from 3,7 million in 2011 to 4 million in 2015 (Widhyharto, 2015, p. 60). At first glance, the Indonesian government's approach seems adequate to address a drug problem because of the dangers and the threats of drugs. Drug abuse kills 12,044 people annually and the economic cost is an estimated Rp. 50 trillion (Widhyharto, 2015, p. 60). Not surprisingly, the government imposes the death penalty on drug trafficking offenders. Unfortunately, public and mass media tend to support it as a manifestation of war on drugs.

However, it is undeniable that the last execution showed that drug policy in Indonesia has another side. Freddy Budiman, a death roll inmate, made a testimony through a lengthy article that was written by Haris Azhar, the Coordinator of committee for missing persons and victims of violence (Kontras), on social media that he had given Rp. 450 billion to the BNN and Rp. 90 billion to certain officials at the National Police and the Excise and Customs ("Pelajaran Dari Pengakuan", 2016, p. 1). The involvement of police officers of abusing their power to gain benefits from drug trafficking is not a secret at grassroots level. Nonetheless, Freddy Budiman's testimony confirms that law enforcement professionals are not free from drug trafficking.

At the same time, President Joko Widodo ironically neglects the rehabilitation of drug abusers due to budget cuts. Consequently, the Social Affairs Ministry will be able to rehabilitate just 9,000 drug abusers next year. The budget is smaller compared to this year's Rp. 87 billion that can rehabilitate 15,000 drug abusers. Meanwhile, the BNN's budget allocation in order to pursue drug traffickers is tripled to Rp. 2.1 billion, and the National Police's budget is also increased by the government ("Pemerintah Jokowi Potong Dana", 2016).

Perhaps Presiden Joko Widodo feels that he has been working very hard to solve the drug problem in Indonesia. Nevertheless, as mentioned earlier, drug policy in Indonesia still emphasizes law enforcement (Lai et al., 2013, p. 1) and ignores the fate of drug abusers. The phenomenon raises a number of questions. What are President Joko Widodo's considerations to conduct this policy? Is it purely because of the dangers and the threats of drugs, state sovereignty, or other considerations? In order to answer those questions, it is not easy. Nonetheless, this paper attempts to provide initial answers by conducting a literature review to trace the origin of war on drugs and its dynamics in Indonesia. Before further explained, this paper initially shows an overview of the emergence and the development of war on drugs on global scale. It is crucial as drug policy in Indonesia was not born in vacuum situation and in a matter of weeks and months.

\section{War on Drugs}

The terminology of war on drugs refers to the government's efforts around the world to enforce the law against drugs in their own countries like war on the battlefield. Consequently, traffickers, users and abusers of drugs are portrayed as enemies of the state. Not surprisingly, the law is changed to ensure that maximum sentence awaits individuals who are proved guilty, and if imprisoned they serve long jail terms (Chepesiuk, 1999, pp. 261-262). The war on drugs had its origins in the United States during 1970s (Fisher, 2006, p. 4; Measham dan South, 2012, p. 699). At the time, President Nixon attempted to mobilize public in the US and raised sentiments against crimes in several US cities (Measham dan South, 2012, p. 699). However, President Reagan was the first leader who declared war on drugs in 1980s (Bagley, 1988, p. 189; Measham dan South, 2012, p. 699). Despite the fact that cocaine and marijuana epidemic was still in its infancy, the attention of mass media was directed to seizure of cocaine in Florida which was from Colombia and transported via Panama. At the same time, marijuana fields in Mexico were destroyed and violence due to drugs took place in Central America (Fisher, 2006, p. 5).

George Bush and Bill Clinton, as the 
successors of Reagan, followed the same approach as well by spending more than millions of US dollars to combat drug trafficking (Chepesiuk, 1999, p. xix; Fisher, 2006, p. 5). Although Bush and Clinton had similar campaigns, Bush (1989-1993) implemented more extreme policy by involving military intervension against Colombia's drug cartels (Luty, 2016, p. 245). President Obama reformed US drugs policy by promoting public health (Sirin, 2011, p. 93). Nonetheless, it was not sufficient to answer the drug problem as it did not solve structural issues, such as poverty, low educational level and health care, recovery of the right of civil society, and criminal justice reform (Sirin, 2011, p. 96).

War on drugs in the US generally consists of supply reduction and demand reduction. Supply reduction comprises three components, namely law enforcement, prohibition, and international effort. On the law enforcement side, the US government attempts to stop drug production and distribution. The prohibition includes some efforts to reduce drug distribution from other countries, for example, checking vehicles in the US borders. On the global scale, the US government collaborates with other countries to destroy marijuana fields and arrest drug cartels. Demand reduction comprises prevention and treatment. In order to prevent drug abuse, the US goverment underscores to stop drug abuse among youth. Treatment is carried out by providing services for drug abusers (Fisher, 2006, pp. 6 $-7)$.

The illustration, as said above, looks appropriate in order to tackle the drug problem. However, drug abusers, especially youth, were on the rise approximately 50 percent. In 1991, at least 11,2 percent of youth was drug abusers. In 2005, the number of drug abusers increased to 16,3 percent (Fisher, 2006, p. 1). In addition, war on drugs causes much more the US citizens on the jails in America's history (Chepesiuk, 1999 , p. 262) and the police brutality to black people as a minority group (Cooper, 2015 , p. 8). Nevertheless, war on drugs is still believed effectively to reduce drug supplies so that the prices go up (Fisher, 2006, p. 1). Even the US federal government assumes that it is appropriate and the US government encourages other countries to adopt the same policy. In fact, the policy is not only inappropriate, but it interferes the sovereignty of other countries as well (Jensen et al., 2004, p. 102). The US government indirectly also spreads war on drugs through both international treaties (Chabat, 2002, p. 142) and popular cultures, such as movies, tv shows, and video games (Mercille, 2014, p. 124). Under Clinton administration, the US had 23 countries as allies to fight drugs (Jones, 1998, p. 41). Not surprisingly, the US emerges as a global power to combat the drug problem (Bagley, 1988, p. 195).

Several scholars criticizes the US drug policy as it is not the result of unbiased, honest and balanced benefits and dangers of drug researches (Rowan, 2016, p. 3). Chomsky (2011/2015, p. 77), for instance, opposes war on drugs in the US since it has political agenda domestically and internationally. In the late 1980's, the US government successfully twisted its citizen's logic. At the time, a majority of its citizens argued that the budget deficit was the biggest problem in the US. However, as mass media portrayed drug issues excessively, public attention changed dramatically from 3 percent to 40 percent or 45 percent on an open pool. Chomsky (2011/2015, pp. 78-79) contends that the US approach is not appropriate to tackle the real problem taking place in the society. The death rate because of drug abuse was 3.500 per year. The number was much smaller than the death rate due to tobacco and alcohol, approximately 300.000 and 100.000 respectively. Marijuana users even opted cocaine, that is much more dangerous, as it was easier to hide. At this point, president's rhetoric and mass media's supports indeed play a pivotal role to influence public perception (Oliver et al., 2011, p. 465) and cause moral panic in the drug problem (Schack, 2011, p. 151).

On the global level, the US government ironically imposed sanctions to Thailand as it limited the US's import and tobacco advertisement (Chomsky, 2011/2015, pp. 78-79). In Colombia, the burning of cocaine fields is not able to decrease drug production, but it simply displaces the production 
to other areas, particularly forest, and causes environmental issues. Even, local communities suffer health problem due to its smoke, and they are forced to leave their territories (Rincón-ruiz dan Kallis, 2013, p. 61). In Mexico, war on drugs, which is controlled by the US, can not be separated from neoliberalism's agenda to expand extractive business (Paley, 2015, p. 117). Ironically, since 2006 at least 50.000 Mexican has died in the war on drugs (Valenzuela, 2013, p. 274). War on drugs also causes black people as the major enemy and they are excluded from their daily life in Canada. Besides, their social capital fades away due to war on drugs (Khenti, 2014, p. 194). Furthermore, the approach simply aims at legitimizing the US intervention and hegemony in Central America (Morales, 1989, p. 151) and it is not able to reduce availability, price, and drug abuse (Bagley, 1988, p. 190).

Not surprisingly, public and international bodies question the effectiveness of war on drugs. The US citizens, for example, did not believe if its government's policy could be success. At least 63 percent of the US citizens argued that drug policy was stagnant or even worst in 2009. Consequently, war on drugs indicated a failure (Scherlen, 2012, p. 68). Global Commission on Drugs also published the failure of war on drugs in 2011. On the report, Global Commission On Drug Policy (2011, p. 4) says that the policy is not effective to decrease drug demand around the world. The number of opium users increased from 12,9 millions in 1998 to 17,35 millions in 2008 , cocaine users rose from 13,4 millions to 17 millions, while marijuana users increased from 147,4 millions to 160 millions. War on drugs does not only spend a lot of money, but also justifies repressive measures to drug traffickers and abusers. The result, however, is far from target that is decided as the arrest of drug dealers is followed by the emergence of other organizations. Even repressive measures hamper attempts to address HIV/ AIDS, overdose, and other harmful consequences.

In 2014, London School of Economics Expert Group on the Economics of Drug Policy's report shows the similar conclusions. War on drugs leads to the arrest of much more people in the US, repressive measures in Asia, corruption and political instability in Afghanistan and West Africa, violence in Latin America, HIV epidemic in Russia, and lack of pain killers and human right abuses around the world (Arrow et al., 2014, p. 3). Although it is highly complex, several global leaders took an advanced measure after the publication of Global Commission on Drugs. Colombia President Juan M. Santos, for instance, encouraged the US government, the leaders of South America countries, and international communities to discuss drug regime. It was followed by Otto Perez Molina, the former of Guatemala's President, to include in the discussion (Mejia dan Restrepo, 2014, p. 26). Nevertheless, what happened in Latin America is completely different to the current situation in Indonesia. When a number of scholars and activists condemns war on drugs since its strategy utilizes forced rehabilitation and death penalty (Kontras, 2015, p. 1), President Joko Widodo still adopts it. International pressures even do not change his policy. At this point, once again, what are the President's considerations? How about its implication?

\section{War on Drugs in Indonesia}

Since colonial era, production, trade and consumption of drugs have been existing in Java (van Luijk dan van Ours, 2001, pp. 2-3). Nevertheless, the origin of war on drugs at least took place in the New Order. Under Soeharto administration, Indonesia declared implicitly as the first country in South East Asia that killed criminals, including drug traffickers and abusers. However, a number of literatures had not mentioned that war on drugs existed at the time. In fact, state through a trained unit, called Petrus (mysterious shooters) shot and killed criminals, drug traffickers and abusers as well, in 1980s (Bourchier, 1990, p. 177; van der Kroef, 1985, p. 749).

At the time, youth in several cities abused methamphetamine and ecstasy. Nonetheless, Indonesia was not categorized as a drug producer or drug user country if compared to other countries in the Golder Triangle (Haseman, 2011, p. 363), 
mountainous region with an area 150.000 square miles and has borders with Myanmar, Laos, and Thailand, that is considered as one of the largest opium cultivation and heroin production in the world (United Nations Office on Drugs and Crime, cited in Chin, 2007, p. 85). As located in the same regional area, state officials and the National Police at the time realized that drug producers and drug traffickers probably would displace the center of drug trafficking to Indonesia (Haseman, 2011, p. 363).

Nevertheless, the Indonesian government simply utilized moral and religious approaches to prevent drug abuse among youth. At least, the Indonesian government believed that the drug problem could be solved by these two measures. Besides, oriental culture was also considered as a wall to prevent drug abuse in Indonesia (Thong, 2011, p. 189). The Jakarta Police chief, Mar. Gen. Soetadi Ronodipoero, for instance, met the religious leaders in Jakarta in 1975. At the time, he emphasized the importance of the religious leaders involvement in order to prevent juvenile delinquency and drug abuse through two forms: (1) verbal (sermons, lectures, and islamic learning forums) in mosques, religious boarding schools, and neighborhood units \& community units; (2) preventive and repressive reporting cooperation with the police officers. The religious leaders supported these two forms and encouraged the severe sentence, even death penalty (Ma'roef, 1986, pp. 278-281)

The approaches led the inadvertence of the government against the dangers and the threats of drugs. Moral and religious approaches simply underscore sin, individual's weakness, and law power to uphold war on drug abusers (Ali and Duse, 2007, pp. 63$64)$, while social dimensions that cause individuals as drug abusers or impede them to get out of the drug problem were not the focus of the Indonesian government. As a result, when Indonesia was hit by crisis in the late 1990s, the government was not prepared to tackle the spread of the drug problem (Thong, 2011, p. 190). According to Drug Addiction Hospital data in Jakarta, the number of patients rose significantly 400 percent since 1996 to 1999 (Purwatiningsih, 2001, p. 38).
Amidst the rising the drug problem that the country faced at the time, the Indonesian government under the helm of President Abdul Rahman Wahid established the National Narcotics Coordination Agency (BKNN). Nonetheless, due to the fact that funding for the agency was dependent on Indonesia police headquarters, operations of BKNN were far from satisfactory (Thong, 2011, p. 190). Under Megawati administration, Indonesia officially declared war on drugs. In March 2002, the President Megawati strengthened national anti drug operations by establishing the National Narcotics Agency (BNN), as a replacement of BKNN that was established in 2000 (Honna, 2011, p. 267). The change had implication to the power and the authority of BNN to coordinate 25 govermental institutions and several operational operations (Thong, 2011, p. 190). In line with that, Megawati instructed all governmental institutions, including on the village scale, to take measures in order to address the drug problem. The campaign simultaneously took place when law enforcement agancies succeeded in seizing the largest drug producing ever recorded in Indonesia in Tangerang in April 2002. That event led to the international community to regard Indonesia as the center of drug trafficking in the South East Asian region (Honna, 2011, pp. 267-268).

BNN has set a long term plan that Indonesia would be free from drugs in 2015. Several international drug syndicates, such as China and West Africa, were identified by $\mathrm{BNN}$ as well. In addition, BNN also showed a report as an evidence to emphasize the dangers of drugs among youth that should not be underestimated, approximately 55 respondents of 64 high schools have abused drugs. Nevertheless, there were a number of challenges and obstacles that could realized the BNN's long term plan. On the long term plan, BNN underscored three aspects, namely: (1) lack of surveillance in the border areas led Indonesia as an archipelago nation that was vulnerable to drug smuggling; (2) economic crisis taking place since 1997 caused limited budget allocation; (3) the capacities of the BNN based on human resources, budget, and equipment was not sufficient to tackle drug issues. Therefore, in 
order to reach the target of drugs' free in Indonesia, those obstacles should be solved (Honna, 2011, p. 269). Not surprisingly, BNN argued that it needed some intervensions, for example: (1) increasing BNN' capatities, budget, and equipments; (2) international cooperation of law enforcement; and (3) the development of treatment and rehabilitation programs. However, the BNN failed to identify the involvement of drug syndicates that had afilitation with political institutions and political actors. Accordingly, despite the fact that the government had intervened some improvements, the number of drug abuse still increased 21 percent from 2002 to 2003 (Honna, 2011, pp. 269-270).

During the era of Susilo Bambang Yudyoyono (SBY), the approach was not completely different by emphasizing law enforcement and it still did not reveal the involvement of political actors in the drug problem (Honna, 2011, p. 270). The condition even worst when SBY was deemed by many groups as he was not firm or subservient to another nation when granting clementy to Schapelle Leigh Corby, an Australian citizen, who was arrested because of smuggling 4,2 kilograms marijuana to Indonesia ("Betapa Istimewanya Corby", 2014, p. 6). Pamungkas (2014, p. 145 ) contends that SBY' measure could not be separated from a friendship between Corby and Baskoro "Ibas" Yudhoyono, the second son of SBY, in Australia. In that country, Ibas abused drugs and was arrested by the Australian government. However, SBY's intervention could release him.

Based on the historical overview of war on drugs in Indonesia as explained above, there are several important points why war on drugs still exists in Indonesia. Firstly, the New Order as the previous generation failed to capture the dangers and the threats of drugs. When Indonesia was not one of center drug trafficking, the government simply relied on law, religious, and moral approaches to deal with drug issues. Consequently, when Indonesia was hit by crisis, those were not sufficient. The New Order was the most responsible to the rampant drug problem. If the New Order could identify it seriously, the drug problem would not be much worst right now.

Secondly, since the New Order until nowadays, the Indonesian government does not have a strong commitment to reveal the involvement of political actors in the drug problem. The government only conducts surveillances to civilians, but the law enforcement professionals are nearly immune to those actions. Since 1970's, the law enforcement professionals have been cooperating with drug traffickers and it has been impeding the rehabilitations and drug trafficking ("Narkotika Atau Kacang", 2016, p. 18). Currently, Freddy Budiman's case is still blur. If the government can not reveal the actors who are behind this case and reform law enforcement professionals, it would not be able to combat drug issues. It is impossible to sweep a dirty floor with a dirty sweep.

Thirdly, being a president, SBY did not show a consistent attitude against drug abuse. Public regarded that his decision to grant clementy for Corby in the early 2014 neglected Indonesia's sovereignty due to the political lobby. In fact, drug issues continued to spread in Indonesia. Moreover, postparole, Corby exposed by mass media lived in an expensive villa Rp. 9 millions per night and she signed a contract with several Autrslian mass media to conduct special interviews that had a contract valued 5 millions Australian dollars or Rp. 54,1 milliars ("Betapa Istimewanya Corby", 2014, p. 6). Fourthly, President Joko Widodo is a product of previous generation who probably believes drug problem can be solved by law enforcement. When the New Order implemented law, moral, and religious approaches, President Joko Widodo was experiencing his youth. The New Order that stressed stability and indoctrinitation perhaps influenced the generation at the time in viewing the drug problem.

Fifth, political affiliation of drug policy (Omori, 2013, p. 520). As mentioned earlier, war on drugs was declared in Megawati era. It is highly possible as a member of The Indonesian Democratic Party of Struggle (PDI-P) under Megawati's leadership, Jokowi continues the same policy and even executes inmates who were pun- 
ished the death sentence. Despite the fact that SBY accentuated the law approach, he postponed death penalty for years. Nico Harjanto, a researcher of Populi Center, argues that SBY's measure aimed at avoiding tension with neighborhood countries on global scale (Aji, 2015). Sixth, war on drugs is a populist policy and has political interests (Oliver et al., 2011, p. 465). It can be clearly traced from the US history. In Indonesia, there is not a comprehensive study to view these two phenomenons. However, mass media and public highly supported President Joko Widodo when three episodes of death penalty exsecuted. In addition, at the time Jokowi-JK was facing three central problems that influenced its administration. The first and second executions took place simultaneously with the Corruption Eradication Commission (KPK) versus the National Police (Polri) issues, while the last one happened at the same time with a cabinet reshuffle.

So, what is the major implication of war on drugs in Indonesia? It is fair to say that war on drugs is a war on young generation. The practice of war on drugs so far is a failure of the previous generation in understanding drug issues. Therefore the drug problem has been never successfully solved, even worst the trend is frequently on the rise. The largest victim of this failure is the lives of young generation. In International Day Against Drug Abuse and Illicit Trafficking 2016, President Joko Widodo said that 49-50 young people are death per day because of drugs (Sekretariat Kabinet Republik Indonesia, 2016). The president's measure to cut rahabilitation budget leads young generation who are drug abusers much more difficult to cure. Moreover, although there is a rehabilitation regulation to drug abusers, in reality they are jailed (Idris, 2016, p. 7) and tortured physically by police officers (Davis et al., 2009, p. 2).

Even if they can be recovered from drug abuse, stigma and discrimination of society will be waiting them. Stigma or discrimination is frequently directed not only to drug abusers, but also to the former of drug abusers (Buchanan, 2006, p. 10). The majority of the former of drug abusers, for instance, could not be employed in the formal sector. In addition, skill trainings post rehabilitation are not provided to them. At this point, their opportunity to come back to 'drug world' is exteremely possible because people regularly perceive that drug abusers and the former of drug abusers have bad moral (Mckeganey et al., 2004, p. 348)

\section{Social Exclusion and Drug Abuse}

As the problems explained above, a solution to get out of the trap of war on drugs is imperative in order to solve drug issues in Indonesia. If it is not war on drugs, what is the approach that we can utilize to address the drug problem? Moreover, drug issues threaten this country. Admittedly, the new measure is an prevention effort. However, in this context, the prevention is not limited to socialization and tended to ceremonial events (Siagian, 2015). More than that, the prevention that this paper offers is the prevention process so that individuals or groups are not excluded from social dimensions. This attempt often can not be viewed by the government that emphasizes law, moral, and religious approaches. Before elaborating it futher, this paper is going to explain an overview of social exlusion.

The terminology of social exclusion was adopted by French Republic Party for the first time to illustrate the dangers of social fragmentation in the early 1970s (Koller dan Davidson, 2008, p. 307). It spreaded to the several European Union (EU) member countries ten years later. In 2001, for example, The Social Protection Committee of the EU (cited in Bhalla dan Lapeyre, 2004 , p. 53) set 10 indicators of social exclusion, namely low income rate, distribution of income, persistence of low income, median low income gap, regional cohesion, long-term unemployment rate, people living in jobless households, early school leavers, life expectancy at birth, selfperceived health status. Gordon (2007, p. 201) argues that the indicators emphasize four aspects, financial poverty, employment, health and education.

Social exclusion is gradually exemplified to poverty and disadvantage (PercySmith, 2000, p. 4). In fact, these three 
concepts have differences. Poverty, for instance, focuses on the distribution of resources to needy individuals and households (Burden cited in Percy-Smith, 2000 , p. 4). On the other hand, disadvantage focuses on "the interaction between lack of material resources and the provision of social services and supports" (Oppenheim cited in Percy-Smith, 2000, p. 4). Social exclusion is completely different to poverty and disadvantage, Millar (2007, p. 3) contends that the definition of social exclusion refers to "the inability of people to participate in the society in which they live, and arguing that this applies across several dimensions, including the material but also the social and political." Consequently, poverty, disadvantage, and social exclusion can not be generalized. Furthermore, Atkinson (1998, p. 1) says that "people may be poor without being socially excluded... people may be socially excluded without being poor."

So, why is the prevention of individuals and groups from social exclusion crucial to solve drug issues? Let us look at the details. In reality, the drug problem is dominantly approached by three aspects, health, psychology, and law. These three approaches indeed help us to understand the drug problem, but they are not sufficient to figure out social components, such as structural inequality or discrimination, of drug abusers. In fact, the social components, which refer to social exclusion (see Buchanan, 2004), often precede drug issues and become a stumbling block for drug abusers. Not least, for example, drug abusers that do not have skills and confidents fail to escape from drug problem (Buchanan, 2004, p. 390).

So far, some scholars shows that the relation of social exclusion and drug abuse. Buchanan and Young (1995, pp. 7-8) denote that $40 \%$ of 50 samples of drug abusers in Sefton, Merseyside, England, do not accomplish their study and that only $22 \%$ can obtain educational qualification. In addition, half of samples do not have jobs for more than 5 years, $12 \%$ of them even worst never work, and only two people who work from 50 people when interview conducted. Not surprisingly, job opportunity is believed as an answer of drug abuse.
Another example could be learned from Pearson (1987). In his paper, Pearson (1987, pp. 62-63) explains that the strong relation of mass unemployment in the UK and heroin abuse in 1970s. Admittedly, the level of heroin abuse of individuals were not same due to the provision and the opportunity of heroin. Nonetheless, the impact of mass unemployment led to heroin abuse significantly on individual, family, and society level. Unemployment even caused individuals much more difficult to escape from heroin addiction. Melrose (2006, p. 36) also stressed that youth drug abuse who were not advantaged could not be saparated from social exclusion. The increase of heroin abuse in 1980s in the UK, for instance, emerged simultaneously with mass unemployment that took place in a long period.

From friendship relation, drug abusers also experience social exclusion. In their research of 30 drug and alcohol abusers in a number of cities in the UK, Neale and Brown (2016, pp. 557-563) finds that third of them do not have friends and some of them denies to have friends. More surprisingly, all of respondents have poor mental \& physical health and capacities (education, training, and job). In Granada and Seville, in Spain, March et al. (2005, p. 441) shows that 73,3 percent of 391 drug abusers only study less than eight years. From job aspect, 53,2 percent depents on illegal activity to meet their needs. In addition, 62,4 percent are imprisoned. In other words, they have low education, while criminal activity can not be saparated from their daily life.

At the macro level, Stevens et al. (2007, pp. 390-391) finds that several indicators, for example, education level, unemployment, health issue, friendship relation, and many others, are also experienced by drug abusers in a number of countries in Europe, such as Swiss, Austria, Germany, and England. In Swiss, drug abusers tend to have high education level and low unemployment level, and they are more satisfied with their conditions compared to England, Austria, and Germany. Drug abusers in England experience more serious social exclusion 
based on education level and employement level, while drug abusers in Germany have the greatest social exclusion based on all indicators than the other three countries.

Based on literature review, Neale (2006, p. 4) elaborates that drug abuse can be looked from a number of dimensions of social exclusion. Firstly, community deprivation. By citing a Drug Strategy Directorate's report in 2002, Neale (2006, p. 4) explains that people living in deprived neighbourhoods often sell drugs to obtain money compared to other legal activities. At the same time, drug abusers, cited by Neale (2006, p. 4) from Drug Strategy Directorate's report, trigger crimes, such as burglary and robbery. Secondly, unemployment. The relation of unemployment and drug abuse can not be saparated from lifestyle, personal, health, and other factors. Drug abusers, for example, are not able to maintain normal working hours. In addition, the performance of drug abusers can not be maximum to do their jobs. Drug abusers daily visits to a pharmacy to collect prescribed medication can disrupt the working day. Even the employers frequently do not want to hire the former of drug abusers because they are difficult to be believed (Neale, 2006, p. 5).

Thirdly, homelessness. According to Neale's research in Scotland in 2002, 136 $(68 \%)$ respondents of 200 drug abusers were homeless, and 63 (32\%) respondents were homeless when the research conducted (Neale, 2006, p. 6). Fourthly, poor health. It is undeniable that drug abuse affects poor health and death. Nonetheless, poor health has various aspects related to social exclusion. For example, poor health leads unemployment, homeless, socially isolated. Those who experience them are likely to misuse drugs as an antidote to dull the boredom and isolation (Neale, 2006, p. 6). Fifth, crime. By citing a Drug Strategy Directorate's report in 2001, Neale (2006, p. 7) shows that nearly two thirds of persistent offenders are hard drug abusers. Even nearly three quarters committed crimes when they were 13 and 15 years old.

So, what about social exclusion study in Indonesia? Syahra (2010, pp. 24-25) reveals that social exclusion actually has a strong relation to the history of Indonesia despite the fact that its emergence is completely different to the situation in Europe. Exclusive rights that were obtained by priyayi (a traditional Javanese administrative class), which are not got by common people in the era of Javanese Kingdom, are an evidence. In addition, Syahra (2010) also says that some researches of social exclusion have emerged. Sudjadmiko (cited in Syahra, 2010, p. 28), for example, elaborates capitalism that excludes lower class in accessing health care. Setyawati, (cited in Syahra, 2010, p. 28) contends that the dominant symbol of the majority of the religion in public space excludes people. Kusumasari (2014) finds that youth sensitivity to social issues on social media has not been captured by the government. As a result, they are excluded in the formulation of government policies.

However, the application of social exclusion is still very limited in the policy formulation in Indonesia (Syahra, 2010, p. 29), and it is not exception in drug issues as well. In fact, Nasir et al. (2014, pp. 345-346) finds that jobs and the educational attainment influence youth in slum area in Makassar to stay away from drugs. At the macro level, in the late 1990s, as mentioned before, drug issues spreaded imostanesly along with crisis. It is actually not completely different to drug abuse taking place in the UK in 1980s.

The limited application of social exclusion alleviation is very unfortunate. As we know, social policy in Indonesia takes a new phase through universal social security. It was completely different compared to a few decades ago, in which the government had an alibi, which people had had traditional social security, to refuse the provision of universal social security (Kiswanto, 2005, p. 92). Indeed traditional social security still exists dan is able to cope with people's problems nowadays (see Harsono, 2014). However, the existence of universal social security is a symbol that the government does not ignore its citizen's welfare. In addition, the commitment of the government to health care and education is increased recently when President Jokowi launched the 
Indonesia Health Card (KIS), the Indonesia Smart Card (KIP) and the Prosperous Family Card (KKS). Another program, the School Operational Aid, is still implemented by the government. Those programs are not only to improve people's welfare, but also to prevent people from social exclusion.

Stevens (2012) shows that the improvement of social policy -along with decriminalization of drug abusers (see Hughes dan Stevens, 2010)-, is essential to decrease drug abuse in Portugal. In that country, drug policy reform decriminalized drug abusers are able to solve social exclusion. The Indonesian government, for instance, can consider that the possession of personal drugs are not criminal offences, but administrative offences. Therefore, drug abusers will not be stigmatized as criminals, but treated as patients (see "Portugal's Drug Policy", 2009). At the same time, this approach will encourage drug abusers to report to the official professionals if they are drug addicts without the fear of the imprisonment.

From the social aspect, state's intervention in social policy can reduce drug abusers, promote them from drug addiction, and return them to their social life. Stevens (2012) states that a guaranteed minimum income, an expansion of social security, an unemployment benefit and job opportunities prevent individuals as drug abusers. It is also significant to improve the quality of the rehabilitation and the skill and confident trainings for the drug abusers. Last but not least, drug counseling for the family members of the drug abusers can not underestimated as its aims at raising awareness among them so that they can support their family to get out of the drug problem. In order to implement those things, it requires careful studies. Not surprisingly, the studies of social exclusion in general and in particular social exclusion and drug abuse are crucial to identify the causes and the stumbling blocks of the drug problem in Indonesia. Consequently social policy formulated from the studies can be directed to address the drug problem.
Amidst the dangers of drugs, President Joko Widodo still sticks to the law enforcement approach as the best way to resolve it. The Jokowi's step actually can not be separated from the history and dynamics of Indonesian drug policy. It leads to the war on young generation because the rampant drug problem recently is the failure of the previous generation to understand it. In the place where it has its origin, the US, war on drugs has absolutely failed to achieve its goals. Even some global leaders have abandoned war on drugs as it is ineffective to resolve the drug problem.

Several scholars in Europe has been developing social approach in viewing drug issues as individuals can not be separated from social dimensions, and those who can not participate, there is a chink that opens opportunities to be drug abusers. Consequently, identification of social exclusion leading individual or groups as drug abusers and experiencing stigma are crucial. By recognizing them, social policy as an instrument to address social exclusion can be implemented to prevent the risk of drug abuse. Portugal's success to decrease the number of drug abusers is the development of social policy and the decriminalization of drug abusers. Portugal does not uphold war on drugs, even war on drug abusers because its leader realizes that war on drugs is unwinnable.

\section{REFERENCES}

Aji, Yogi Bayu. 2015, 7 Maret. Peneliti: Putusan Vonis Mati di Era SBY, Jokowi Hanya Jalankan Eksekusi. Metrotvnews. http://news.metrotvnews.com/ $\mathrm{read} / 2015 / 03 / 07 / 367840 /$ penelitiputusan-vonis-mati-di-era-sby-jokowihanya-jalankan-eksekusi. Diakses 23 Oktober 2010.

Ali, M. Amrin P dan Duse, Imran. 2007, Narkoba Ancaman Generasi Muda, Pustaka Timur. Kaltim

A., S. dan Lapeyre, Frederic. 2004. Poverty and Exclusion in a Global World $2^{\text {nd }}$ revised and enlarged edition. Palgrave Macmillan. Basingstoke.

\section{CONCLUSION}


Arrow, K., Castro, L. F. C., Clegg, N., Collier, P., Cox, M., Uribe, A. G., ... Williamson, O. 2014. Ending the Drug Wars: Report of the LSE Expert Group on the Economics of Drug Policy. LSE Ideas.

Atkinson, A.B. 1998. Social Exclusion, Poverty and Unemployment. Exclusion, Employment and Opportunity. Editor A.B. Atkinson dan J. Hills. CASE paper 4, Centre for the Analysis of Social Exclusion, London School of Economics. 1-24.

Bagley, B. M. 1988. US Foreign Policy and the War on Drugs: Analysis of a Policy Failure. Journal of Interamerican Studies and World Affairs. 30 (2/3): 189-212.

Betapa Istimewanya Corby. 2014, 12 Februari. Kompas. 6.

Bhalla, A., S. dan Lapeyre, Frederic. 2004. Poverty and Exclusion in a Global World $2^{\text {nd }}$ revised and enlarged edition. Palgrave Macmillan. Basingstoke.

Bourchier, David. 1990. Crime, Law and State Authority in Indonesia. State and Civil Society in Indonesia. Editor Arief Budiman. Victoria. Centre of Southeast Asian Studies, Monash University. 177-212.

Buchanan, Julian. 2004. Missing Links: Problem Drug Use and Social Exclusion. Probation Journal Special Edition on Problem Drug Use. 51 (4): 387 -397 .

Buchanan, Julian. 2006. Understanding Problematic Drug Use: A Medical Matter or a Social Issue?.https:// www.researchgate.net/

publica-

tion/228891046_Understanding_proble matic_drug_use_a_medical_matter_or a_social issue. Diakses pada 22 Oktober $201 \overline{6}$.

Buchanan, Julian dan Young, Lee. 1995. Drugs Relapse Prevention: Giving Users a Voice, A Report for Bootle Mari- time City Challenge. The University of Liverpool. Liverpool.

Chabat, Jorge. 2002. Mexico's War on Drugs: No Margin for Maneuver. Annals of the American Academy of Political and Social Science. 582 (1). 134 -148 .

Chepesiuk, Ron. 1999. The War on Drugs: An International Encyclopedia. ABCCLIO. Santa Barbara.

Chin, Ko-lin. 2007. Into the Thick of It: Methodological Issues in Studying the Drug Trade in the Golden Triangle. Asian Journal of Criminology. 2 (2): 85-109.

Chomsky, Noam. 2015. How the World Works. Terj. Tia Setiadi. Penerbit Bentang. Yogyakarta. (Karya asli dipublikasi pada 2011).

Cooper, H. LF. 2015. War on Drugs Policing and Police Brutality. Subst Use Misuse. 50 (8-9): 1188-1194.

Davis, S. L. M., Triwahyuono, A., dan Alexander, R. 2009. Survey of Abuses Against Injecting Drug Users in Indonesia. Harm Reduction Journal. 6 (28): 1-6.

Fisher, Gary L. 2006. Rethinking Our War on Drugs: Candid Talk about Controversial Issues, Praeger Publishers. Amerika Serikat.

Global Commission on Drug Policy. 2011. War on Drugs: Report of the Global Commission on Drug Policy. Global Commission on Drugs.

Gordon, David. 2007. History and Development of Social Exclusion and Policy. Multidisciplinary Handbook of Social Exclusion Research. Editor D. Abrams, J. Christian dan D. Gordon. John Wiley and Sons Inc. Chichester. 192-210.

Harsono, Wiji. 2014. Jimpitan, Modal Sosial yang Menjadi Solusi Permasalahan Masyarakat. Jurnal Kebijakan dan Administrasi Publik. 18 (2): 131-145.

Haseman, John B. 2011. National Security. Indonesia: A Country Study. Editor William H. Frederick dan Robert L. 
Worden. U.S. Government Printing Office. Amerika Serikat. 312-366.

Honna, Jun. 2011. Orchestrating Transnational Crime Security Sector Politics as a Trojan Horse for Anti-Reformists. The State and Illegality in Indonesia. Editor Edward Aspinall dan Gerry van Klinken. KITLV Press. Leiden. 261279.

Hughes, C. E., dan Stevens, A. 2010. What Can We Learn From The Portuguese Decriminalization of Illicit Drugs?. British Journal of Criminology. 50 (6): 999-1022.

Idris, Aradila Caesar Ifmaini. 2016, 24 Agustus. Remisi Untuk Koruptor. Kompas. 7.

Jensen, Eric L., Jurg Gerber, dan Clayton Mosher. 2004. Social Consequences of the War on Drugs: The Legacy of Failed Policy. Criminal Justice Policy Review. 15 (1): 100-121.

Jones, Hal. 1998. The Limits of Pressure: US Policy Failures in the International War on Drugs. Harvard International Review. 20 (2): 38-41.

Khenti, Akwatu. 2014. The Canadian War on Drugs: Structural Violence and Unequal Treatment of Black Canadians. International Journal of Drug Policy. 25 (2): 190-195.

Kiswanto, Eddy. 2005. Negara Kesejahteraan (Welfare State): Mengembalikan Peran Negara Dalam Pembangunan Kesejahteraan Sosial di Indonesia. Jurnal Kebijakan dan Administrasi Publik. 9 (2): 91-108.

Koller, Veronica dan Davidson, Paul. 2008. Social Exclusion as Conceptual and Grammatical Metaphor: A CrossGenre Study of British Policy Making. Discourse and Society. 19 (3): 307331.

Kontras. 2015. Rilisan Media: Akademisi dan Aktivis Indonesia Menghimbau Respon Berbasis Bukti dengan Pendekatan Kesehatan Masyarakat Untuk Penggunaan Narkotika di Indonesia. http://kontras.org/lampiran/

Rilisan_media_bahasa_final5Jun.pdf.

Diakses pada 1 Agustus 2016.

Kusumasari, Bevaola. 2014. Social Media dan Eksklusi Remaja dalam Perumusan Kebijakan Publik. Jurnal Kebijakan dan Administrasi Publik. 18 (2): 119-129.

Lai, Gloria, Fransiska Amin, dan Ruth Birgin. 2013. Drug Policy in Indonesia. International Drug Policy Consortium (IDPC). Briefing Paper. January.

Luty, Jason. 2016. The Beginning of The End of Prohibition: The Politics of Drug Addiction. BJPscyh Advances. 22 (4): 242-250.

March, J. C., Oviedo-Joekes, E., dan Romero, M. 2005. Injection and NonInjection Drug Use Related to Social Exclusion Indicators in Two Andalusian Cities. Drugs: Education, Prevention and Policy. 12 (6): 437-447.

Ma'roef, Ridha. 1986. Narkotika, Bahaya, dan Penanggulangannya. Karisma. Jakarta.

Mckeganey, N., Neale, J., Parkin, S., dan Mills, C. 2004. Communities and Drugs: Beyond The Rhetoric of Community Action. Probation Journal. 51 (4): 343-361.

Measham, Fiona dan Nigel South. 2012. Drugs, Alcohol, and Crime. The Oxford Handbook of Criminology Fifth Edition. Editor Mike Maguire, Rod Morgan dan Robert Reiner. Oxford University Press. Oxford. 286-716.

Mejia, Daniel dan Restrepo, Pascual. 2014. Why is Strict Prohibition Collapsing? A Perspective from Producer and Transit Countries. Ending the Drug Wars: Report of the LSE Expert Group on the Economics of Drug Policy. Editor John Collins. LSE Ideas. 26-32.

Melrose, Margaret. 2006. Young People and Drugs. Drugs, Policy and Politics. Editor R. Hughes, R. Lart, dan P. Higate. Open University Press. Maidenhead. $31-44$

Mercille, Julien. 2014. The Media- 
Entertainment Industry and the "War on Drugs " in Mexico. Latin American Perspectives. 41 (195): 110-129.

Millar, Jane. 2007. Social Exclusion and Social Policy Research: Defining Exclusion. Multidisciplinary Handbook of Social Exclusion Research. Editor D. Abrams, J. Christian dan D. Gordon. John Wiley and Sons Inc. Chichester. 1 -15 .

Morales, W. Q. 1989. The War on Drugs: A New US National Security Doctrine?. Third World Quarterly. 11 (3): 147169.

Narkotika atau Kacang Goreng. 2016, 8-14 Agustus. Majalah Tempo. 18.

Nasir, S., Rosenthal, D., dan Moore, T. 2014. Drug Use Among Young Men in a Slum Area in Makassar, Indonesia. International Journal of Criminology and Sociology. 3 (2014): 336-347.

Neale, Joanne. 2006. Social Exclusion, Drugs, and Policy. Drugs, Policy and Politics. Editor R. Hughes, R. Lart, dan P. Higate. Open University Press. Maidenhead. 1-17.

Neale, Joanne dan Brown, Caral. 2016. "We are Always in Some Form of Contact": Friendships Among Homeless Drug and Alcohol Users Living in Hostels. Health and Social Care in the Community. 24 (5): 557-566.

Oliver, W. M., Hill, J., dan Marion, N. E. 2011. When the President Speaks . . . An Analysis of Presidential Influence Over Public Opinion Concerning the War on Drugs. Criminal Justice Review. 36 (4): 456-469.

Omori, M. K. 2013. Moral Panics and Morality Policy: The Impact of Media, Political Ideology, Drug Use, and Manufacturing on Methamphetamine Legislation in the United States. Journal of Drug Issues. 43 (4): 517-534.
Paley, Dawn. 2015. Drug War as Neoliberal Trojan Horse. Latin American Perspectives. 42 (5): 109-132.

Pamungkas, Sri-Bintang. 2014. Ganti Rezim Ganti Sistem:Pergulatan Menguasai Nusantara. El Bisma. Jakarta.

Pearson, Geoffrey. 1987. Social Deprivation, Unemployment, and Patterns of Heroin Use. A Land Fit for Heroin? Drug Policies, Prevention and Practice. Editor Nicholas Dorn dan Nigel South. Macmillan Education. New York. 62-94.

Pelajaran dari Pengakuan Freddy. 2016, 2 Agustus. Media Indonesia. 1.

Pemerintah Jokowi Potong Dana Rehabilitasi Korban Narkoba. 2016, 2 Agustus. DW. http://www.dw.com/id/ pemerintahan-jokowi-potong-danarehabilitasi-korban-narkoba/a19443473. Diakses pada 18 Oktober 2016.

Percy-Smith, Janie. 2000. Introduction: The Contours of Social Exclusion. Policy Responses to Social Exclusion: Towards Inclusion?. Editor Janie PercySmith. Open University Press. Philadelphia. 1-21.

Portugal's Drug Policy: Treating, Not Punishing, 2009, 27 Agustus. The Economist. http://www.economist.com/ node/14309861. Diakses pada 12 April 2017.

Purwatiningsih, S. 2001. Penyalahgunaan Narkoba di Indonesia. Populasi. 12 (1): 37-54.

Rincón-ruiz, A., dan Kallis, G. 2013. Caught in The Middle, Colombia's War on Drugs and its Effects on Forest and People. Geoforum. 46 (2013): 60-78.

Rowan, Michael. 2016. Thank God for (Others') Unanswered Prayers: The Failure of The Drug War ...Cheap Drugs...Lower Rates of Serious Crime...The Logic Adds Up, but What Next?. Dialectical Anthropology. 1-8. 
Schack, Todd. 2011. Twenty-first-century Drug Warriors: The Press, Privateers and The For-profit Waging of The War on Drugs. Media, War \& Conflict. 4 (2): 142-161.

Scherlen, Renee. 2012. The Never-Ending Drug War: Obstacles to Drug War Policy Termination. PS: Political Science and Politics. 45 (1): 67-73.

Sekretariat Kabinet Republik Indonesia. 2016, 26 Juni. Sambutan Presiden Joko Widodo pada Puncak Peringatan Hari Anti Narkotika Internasional (HANI) Tahun 2016, 26 Juni 2016, di Pinangsia Taman Sari, Jakarta Barat. http://setkab.go.id/sambutan-presidenjoko-widodo-pada-puncak-peringatanhari-anti-narkotika-internasional-hanitahun-2016-26-juni-2016-di-lapanganparkir-pinangsia-jakarta-barat/. Diakses pada 22 Oktober 2016.

Siagian, Kristian. 2015, 20 Agustus. Memikirkan Kembali Arah Penanganan Narkoba di Indonesia. Sindonews. http:// nasional.sindonews.com/ $\mathrm{read} / 1034938 / 18 /$ memikirkan-kembaliarah-penanganan-narkoba-di-indonesia -1440032488. Diakses pada 24 April 2016.

Sirin, C. V. 2011. From Nixon's War on Drugs to Obama's Drug Policies Today: Presidential Process in Addressing Racial Injustices and Disparities. Race, Gender \& Class Journal. 18 (3/4): 82-99.

Stevens, Alex. 2012. Portuguese Drug Policy Shows That Decriminalisation Can Work, but Only Alongside Improvements in Health and Social Policies. Blog LSE. http://blogs.lse.ac.uk/ europpblog/2012/12/10/portuguesedrug-policy-alex-stevens. Diakses 1 Agustus 2016.
Werdenich, W. 2007. The Victimization of Dependent Drug Users Findings from a European Study, UK. European Journal of Criminology. 4 (4): 385-408.

Syahra, Rusydi. 2010. Eksklusi Sosial: Perspektif Baru Untuk Memahami Deprivasi dan Kemiskinan. Jurnal Masyarakat dan Budaya LIPI Edisi Khusus. 12 (3): $1-34$

Thong, Denny. 2011. Memanusiakan Manusia: Menata Jiwa Membangun Bangsa. PT Gramedia Pustaka Utama. Jakarta.

Valenzuela, C. M. 2013. The "War on Drugs" and The "New Strategy": Identity Constructions of The United States, U.S. Drug Users and Mexico. Mexican Law Review. 5 (2): 245-275.

Van der Kroef, Justus M. 1985. "Petrus": Patterns of Prophylactic Murder in Indonesia. Asian Survey. 25 (7): 745 759.

Van Luijk, E. W. dan van Ours, J. C. 2001. The Effects of Government Policy on Drug Use: Java, 1875-1904. The Journal of Economic History. 61 (1): 1-18.

Widhyharto, Derajad S. 2015. Biaya Sosial Pencegahan Penyalahgunaan Narkoba di Kampus. UGM Mengajak: Raih Prestasi Tanpa Narkoba. Editor Sri Suryawati, Derajad S. W., dan Koentjoro. Gadjah Mada University Press. Yogyakarta. 60-74.

Stevens, A., Berto, D., Frick, U., Kerschl, V., McSweeney, T., Schaaf, S., ... 
Erwinton Simatupang — Getting Out of the Trap of War on Drugs 